\title{
電子回折法に依る金屬表面構造の研究 ${ }^{*}$
}

山梨大學教授 工學博士 高 橋 昇

\section{1. 絙言}

1924 年フランスの de Broglie に依り電子小波 動性が提唱され，繥いて 1927 年米國の Davisson と Germer がニッケルの單結晶に依り，1928 年 资國の G.P.Thomson が金屬薄膜等に依り, 又 我國の菊池正士が雲母の薄膜に依り, 夫及 de Broglie の說の實驗的證明を行つてから, 電子回 折に對する關心は急激に高まり，初期の基礎的研 究から次第に隹用研究が盛になつて來た。之等の 中 Davisson 等の行つた荱い電子 (15〜370 ボル ト）の间折は實驗的に極めて困難であつた爲, 彼 等以後は殆ど行われなかつたのに對し, Thomson 等の行つた速い電子（數萬ボルト）の间折は舁㠱 乾板による記錄が容易である䈆, 年と共に研究の 數を增し，间折現象目體の理論的及び賽驗的研究， 賽驗技術の改良，固體表面及び薄膜の研究，氣體 分子の構造の各分野に亘つておびただしい業績が あげられた。特に最近は理論も從來の運動壆的理 論から, 進んで動力學的理論(1)を考慮する傾向が 著しく, 實驗技術に於ても真空技術の發達の外, 装置自體に就て電子顯微鏡の技術をとり入れて, 高分解能のものが現われ始め, 回折像解析の方法, 寫真の鮮明さ洪に全?面目を一新している。本稿 では主として應用研究者の立場から，金屬表面構 造の研究に就て述べる事にする。

\section{2. 桔晶に依る雪子の回折}

電子间折は原理的には電子と物質原子との相互 作用を利用するものであるが，その散亂は主とし

* 炤和: 26 年 2 月 1 日，金屬表面技術協會第 2 回定時 總會特別講演

（1）入射波が一つの散骴體に當ると一般に二次波を 生じ, 多くの散硫體があれば之等二次波が互に干 涉し 间折現象を生ずる。二次波は三次波を入三 次波は又四次波を生じ, 又一次波は二次波を出し て弱められる事を考虑せねばならない。之等波全 體の釣合を論ずるものを動力學的理論といい，三 次波以上を分略し，一次波の弱まりを然視して干 涉波を論ずるるのを運動學的理論といら。佮上田

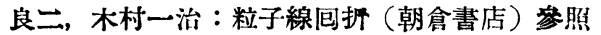

て原子核により行われる䉆, 一回の衝突に依り散 锟される度合が大きく，從つて物質に對する透過 能力は非常に小さん。X線に比して百萬分の一之

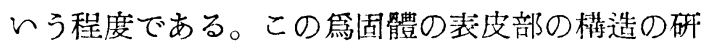
究にはX楾の到底及ぶべからざる利點を有し，他 方薄膜並びに氣體分子の構造の研究にも利用せら れて有力な武器となるのである。

さて表面䛶浩の研究には電了線を試料の表面す れずれに一一記高速電子に對してはde Broglie の式 $\lambda=h / m v$ と電子加速の條件 $e V=-\frac{1}{2} m v^{2}$ か ら得られる波長 $\lambda \doteqdot \sqrt{150 / V} \AA$ ( $h$ は Planck の 常數, $m$ 虫電子の質量, $v$ 注電子の速度, $V$ は加 速電壓, $e$ は電子の電荷, $\boldsymbol{V}$ はボルトで表わした

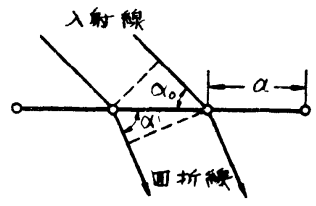

(a)

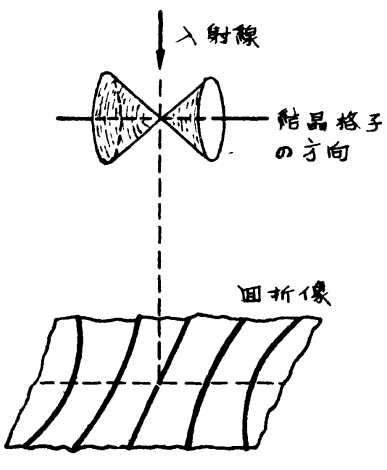

(b)

第1回一次元格于に依る融 于波の回斱（a）一船の場合 (b) 竄靧本面に本行な軸を持 つ格子に直角に電子線が入射 しを場合 (Finch) 加速笔崕)仗 $1 / 100$ 丹̊の桁であるか ら, Bragg の式 $2 d \sin \theta=n \lambda \quad(d$ 柱結晶縦面間隔， $\theta$ は照射角, $n$ は 反射次數）加ら $\theta$ は $2^{\circ}$ 前後になる あてて得られ る包折候を調べる のである。從つて この場合を反射法 と呼び，薄膜の研 究等に暯ける如？ 電子楾を試料面に 值角に當てる透過 法と區别してい る。反射像る諭ず るに先立ち簡單に 包折像を生ずる理 由を說明する。

(i) 一次元格子にに依る四折像 今格子常數 $a$ なる一次元格子に第 1 圆に示す樣な角度で電子線 が大射，散亂されるとするとLaue の條件 $\alpha(\cos$ $\left.\alpha-\cos \alpha_{0}\right)=h \lambda(h$ は整數）が滿足されれれば散狧 
波は强め合う。故に散亂波の强度最大の方向は格 子の軸方向と $\alpha$ なる牱頂角をな少圆錐面上にあ る。從つて之を本面で切れば軸が平面と本行なら ば，一般に双曲線が得られ，格子の位置との距離 ボ大なる時には之等双曲線は近似的に等間隔の古 線群となる。概括的にんうと結晶格子の軸方向と 㨁角に並ぶ㨁線群から成る回折像が得られる。

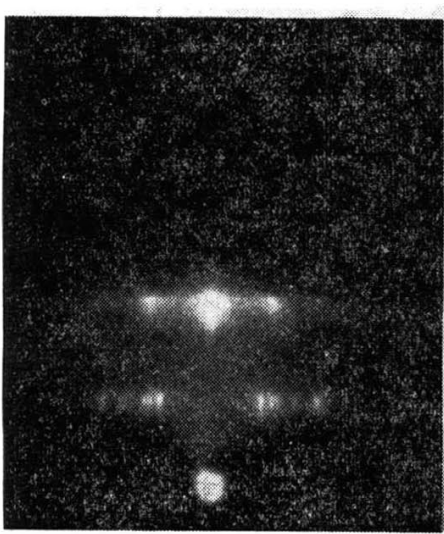

第2、圆クロ嫄虞面上のス テアリン酸單分子屡 ( 7 枚)

第 2 圖はこの一例でクロム琢暫面上のステアリン 酸單分子㕌（7枚）による回折像を示し，各層線 間隔は脂肪酸中の炭素の鑍狀分了にに於ける一つお きの炭素原子の距離 $2.54 \AA$ に對應し，加る鎻 妝分子が金屬面上に直立している事艾表わしてい る。

(ii) 二:次元格了に依る回折像この場合は(i)
第 3 圖は雲桪の薄膜加ら得られた洄折像で，斯る 模樣を一般に $N$ 模樣 (Net の意) と呼ぶ。

(iii）三次元格子に低る间折像この場合例え ば立方晶系結晶を與え，第三の方向が電子線に平 行であるとすると，この方向の政線格子に依る包 丰修は軸方向と乾板面との交點を中心とする同心 圆になる。從つて平面直交格子の交點が，この圆

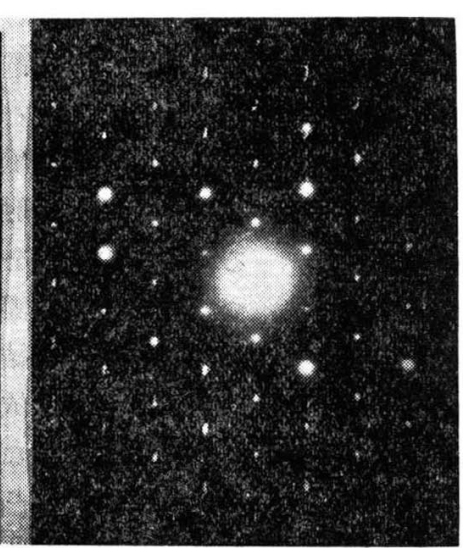

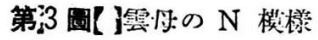

周上にある時に限り， Laue の條件 $a\left(\cos \alpha-\cos \alpha_{0}\right)=\hbar \lambda, \quad b(\cos \beta-$ $\left.\cos \beta_{0}\right)=k \lambda, \quad c\left(\cos \gamma-\cos \gamma_{0}\right)=l \lambda$ が淽足されて间折像を生ずる。（第4 圖）

舒，回折電了線の强度は、武料の位。 置から $R$ なる距谣にに於ては $I=\frac{S^{2}}{R^{2}} \cdot \frac{\sin ^{2} M_{1} h \pi}{\sin ^{2} h \pi} \cdot \frac{\sin M^{2} k \pi}{\sin ^{2} k \pi}$. $\frac{\sin ^{2} M_{3} l \pi}{\sin ^{2} l \pi}$ (但し $M_{1}, M_{2}, M_{3}$ は 夫火 $a, b, c$ 方向に於ける散亂原子. の數を表わし，Sは結晶の構造因子 と稳せられるもので, 結晶队に於け る原子の配置狀沉に關する)なる式で裴わざれる。 之も一次元の場合から順次論じて行けばよい が，此處では評論を避ける事にする。

さて，以上の議論に基ずき反射像を論ずる譯で あるが，之には次の解釋法を用いるのが便利であ る(2)。即ち絬昆琶面が網平面から成立つていると 将元, 原子列 $\mathrm{AB} は$ は略及大射線に本行, 他の列 $\mathrm{CD}$ の組合せを考元れ ば容易に說明せら れる。例えば值交 格子に依る回折像 は縱橫夫及の直線 格子に對し，夫љ 槿緃の直線群包折 像が對應するか ら, 結局その交點 に虽る位置に國折 班䅇が現われる。 之壮 $\alpha(\cos \alpha-\cos$ $\left.c_{0}^{\prime}\right)=h \lambda, \quad b(\cos \beta$ $\left.-\cos \beta_{0}\right)=k \lambda$ が

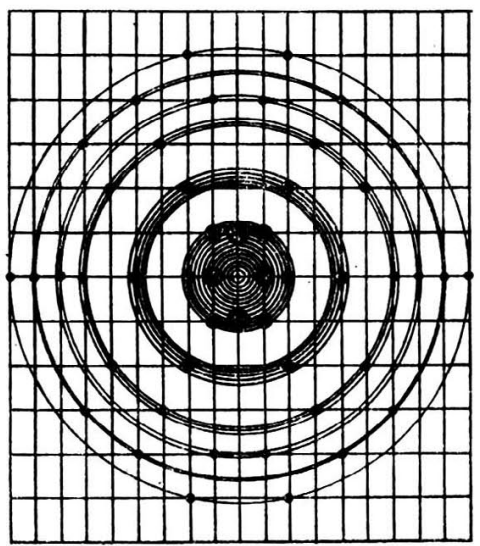

第4圖三次元格子に化る闰折 (Finch)

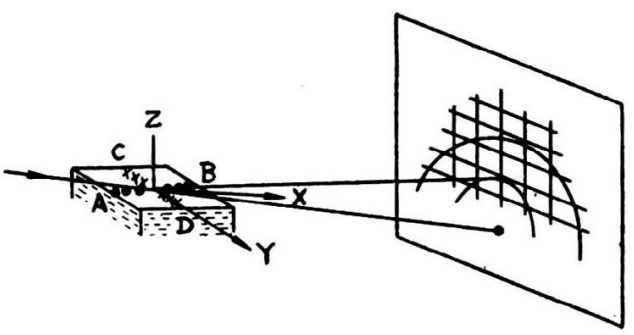

第 5 國 反射法に於ける包折候の筧明 (Kirchner 取び Raether)

同時に䓣足される事に對㗹している。雲持, 輝水 鉛鑛等の擘開浦膜からはこの種の修が得られる。

(2) F. Kirchner u. Raether, Phys. Zeit. 30 510 (1932) 
虻之に正角であるとする(第 5 圖)。この場合二次 波の强合う條件は间折線が $\mathrm{AB}$ 老軸とする圆錐 と $\mathrm{CD}$ に直角な㨁線群との交點に问う事である。 表面に直角な第三の原子列に對しては表面に本行 な直線群が得られる。之等三つが同時に交わる場 命にのみ真の回折條件が萊足导れる譯である。こ の意味からすれば，间折班點は極めて少い事にな る。然し䉓子線の場合に法表面下に透大する事が 栖めて少的爲, 表面に垂直な方向に於ける分解能

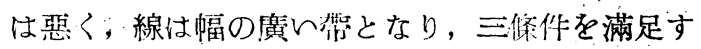
るので, 實際には相當數の班點が得られる。何表 面に於ける結昆の大ざに制限がある場合には， $\mathrm{AB}, \mathrm{CD}$ 二方向の同じ大さに對しては $\mathrm{AB}$ の方が 分解が惡々，從つて圓の友が垂直線よりボケる事 になる。

以上は Laue の條件を基礎として包折條件を吟 味して來たが，電子回折の場合には之等を總括し， 逆格子を用いて包折現象老論ずるのが便利であ る。今單位距離 $a, b, c$ 孝有する結晶格子があう たとすると，之に對する逆格子の單位距﨎山

$a^{*}=\frac{[b c]}{(a[b c])}, b^{*}=\frac{[c a]}{(b[a c])}, c^{*}=\frac{[a b]}{(c[a b])}([]$ は ベクトル積，（）はスタラー積）に依り定義せら れる。嘪際の結晶格子の逆格了を考元る時には構 造因子S 孝併世考え, 之が答の逆格子點を消さね ばならない。一例をあ洋ると格子常數 立方格子の逆格子は一邊方 $2 / a$ なる體心立方格了 であり，格子常數 $a$ な體心立方检了の逆格子小

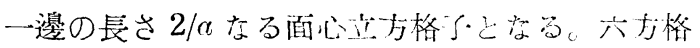
テの逆格子は知長六方格子・である。

さてこの逆格于在使つて電子国折像の解析孝行
うには次の樣にすればよん。電子波の波長が極め て㷵い事加ら，一般に[hkl]なる力向に結晶に電 于䋓を入射せし为る时得られる间折像は, その結 晶格子の逆格子の $(h k l)$ 面の配列を $\lambda L$ 倍 $(L$ は 試料加ら乾板迄の距離)したものである莗が分る。 之から班墨の Miller 指數, 結晶に對する入射線 の方向が求为られる。逆格子察間では結晶の網平 面が點として現われ，回折像の說明には椣めて便 利であるから，電子间折に於ては以上の說明法が 廣く用いられている。

以上簡單に電子回折に於ける結晶解析の理論を 述へた。所で反射像を生ずる際の金屬表面に於け る電子線の狀態を考えると第 6 回に示す如くであ つて, 電子線は固體表面に於ける微小凸起を透過 し，凸起內部の絬晶原子に依り彈性散简をを受け， 散亂波の干涉に依つて回折模樣を生ずるのであ る。從つて鮮明な回折像を得る爲には電子線の透 過を許す銳利な凸起が表面に存在する事が必要で あり，凸起の形狀並じにその數と旬折像との關係 は，恰も光學格子に於ける溝の幅並びにその數之 スペクトルとの關係に類似している。金屬表面に 於ける凹起が平滑化されて圓く，且その數も少さ なれば分解能が減少して包折像がボケ，暈環（公 ロ一）在生ずる事が之から推測される。故に包折 像记㙓面の結晶組織に低る以外に，表皮部の幾何 鼠的微細構造に關係する譯である。今表面に同じ

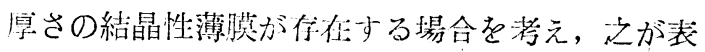
面の『起の形に依り反射像に如们に影響するか子 調へてて見よう。第 7 圖に示す梯な三種の山起を考 元, 皮膜の厚さを $D$, 照射角を $\theta$, 入射側の凸起 の面と水本面とのなす角を $\delta$, 皮膜中の電子線の

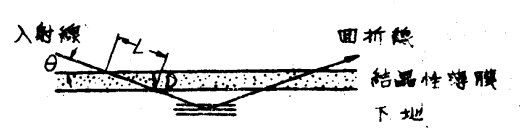

(a)

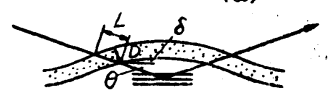

(b)

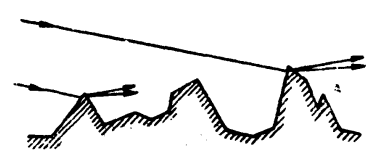

第 6 四的法に於て，表 面に於ける電子線の间折狀 態を示す闻 (Thomson)

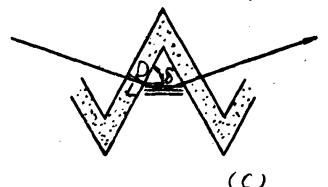

第 7 圖表面の凸起の形に依る 包折狀況の變化 (Raether)

行程をとすると，圖に示した三種 の場合に就て,

(a) 完全な平滑面では

$$
D=L \sin \theta
$$

（b）圓頂凸起では

$$
D=L \sin (\theta+\infty)
$$

（c）銳利な凸起では

$$
D=L \sin \delta, \theta<\delta \delta
$$

となる。一般に $\theta$ は $3 \times 10^{-2}$ ラデ アン (約 $2^{\circ}$ ) であり, $\delta$ は (a) では

(3) F. Kirchner: Nature. 129, 545, (1932) 
$0^{\circ}$ ，(b) では約 5×10-2 ラヂアン，(c) では約 $60^{\circ}$ とすると, (a) では $L=30 D$, (b) では $L=12.5$ $D$, (c) では $L=1.25 D$ となる。同じ厚さ $D$ の 皮膜に對しても, 膜中の電子線の行程は本滑表面 では凸凹の面の 20 倍も長くなり, 皮膜を電子線 に依り檢出し得る程度は本滑面に於ける方が凸凹 面に於けるより遙に大となる譯である。この事は 特に電解研䐴面の樣な微視的な平滑面を調べる際 注意すべき事で，アルミニウムの電解研磨面に於

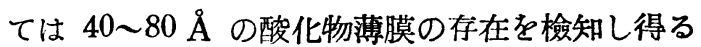
のである(4)。

\section{3. 反射法に於ける代衰的问折像}

反射法に依る间折像は試料の種類に佧り多種多 樣のものが現われるが，ここでは比較的頻繁に現 われる代表的なものに就て說明を加える事にす る。

(a) 同心環 多結晶試料に就て現われる所謂 Debye-Scherrer 環である。多結晶體は相當數の 單結晶の集合體と考えられるから，その回折像は 單結晶に依る班點像を入射線を軸として回轉させ たものが現われる。從つて一般には同心圓の包折 像を得る筈であるが，反射法の場合には試料に依 り略及その牛分が遮られるので, 實際得られるも のは同心牛圓群である。各環の强度は之を生じた 網平面の頻度, 結晶の構造因子, 結晶粒の大さ等 に關係する。第 8 圆に鐵の酸化面 $\left(\alpha-\mathrm{Fe}_{2} \mathrm{O}_{3}\right)$ に 依る四折像を示す。

（b）弧 多結晶試料が緎維組織をなしている 時には，纖維軸が大射線に平行な場合を除き，一 般に圓周に沿つて强度の變化している弧狀の回折 像が得られる纖維組織が完全である程弧の長さは 短り，不完全になる程圆周上の强度變化は認め 難くなる。この種の像は賽用上最も重要なもの で, 試料の表面處理に伴い異つた緎維組織が現わ れる。弧が十分著しい時には蟣維軸の決定は容易 であつて, 乾板上の電子線の入射點を通り試料面 の影に淔角な線上にある弧の Miller 指數 $h, k, l$ が表面に直角な繊維軸を決定する。第 9 圖に壓延 モリブデン板から得られる包折像を示す。この場 合は蟣維組織は完全に近く，板の深部に至る迄織

(4) H. Raether : Métaux et Corrosion. 25, 1 (1959)

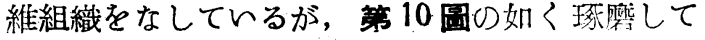
仕上げた表面丈に認められる織維組織もある。之 は表面の極薄層部文に生ずるので，僅の莴蝕に依 り除かれて直ちに地金の組織となる。们表面加ら 得られる繊維組織は，必ずしも內部のそれと一致 しなんからこの點十分注意を要する。

（c） $N$ 模梯 單結晶表面を腐蝕して作つた㭖 料からは第 11・團の如き斑點像が得られる。 の同心環は斯る斑點像を入射點の周りに包轉した ものであり，多結晶試料でも結晶粒の大さが大き んか, 又は電子線を十分細くして照射される結晶 粒の數を少くすれば同心環は斑點狀の像に分れて 來る。倘表面が平滑な場合には電子線が凩折を受 け，斑點は試料面の影に值角に下に延びる（第 12 圖)。

（d）菊池線 天然の結晶の䢃開面の樣に分子 的尺度で, 本滑な表面からは黑白の平行線（陰畫 ならば入射點に近い方が白, 遠い方が黑）が現わ れる(第 13 國)。人工の金屬單結晶では完全な結 晶を得難い第汃かる菊池線が比較的現われ難い が，うま作つた歪のなん狀態の單結晶からは屡 及菊池線が現われ，結晶の完全さの目安になる。 尤も天然の結晶から程の鮮銳な線は中及得られな n。

（e）八ロー 金屬表面が非結晶性の皮膜で蔽 われているか，或は表面の凸凹が極めて少 平滑 な場合には第 14 圖の如きハローが得られる。然 乙金屬表面は極めて污れ易门，有機性薄膜で蔽わ れてこの爲八ローを生ずる事が多いから，八ロー の解釋には細心の注意を要する。

以上が代表的な反射像であるが，之等は單獨に 現われる事もあり，幾つか組合つて同時に現われ る事もある。夫及に就て周到な配慮が必要である。

\section{4. 軍驗上の注恶}

電子回折實驗一般に關する說明は限ら岂た範圍 內では到底不可能であるから，ここでは金屬表面 を試料として用いる際の注意を述べておく。電子 線が表面薄膜の存在に極めて敏感である虑，表面 の污染には極めて神經質にならねばならない。試 料を手で持つ等は論外で，バーナ゙一等の焰で燒い て清潔にしたピンセットを用うべきである。酸化 面の樣に加熱されて，始めにたとい有機物薄膜が 


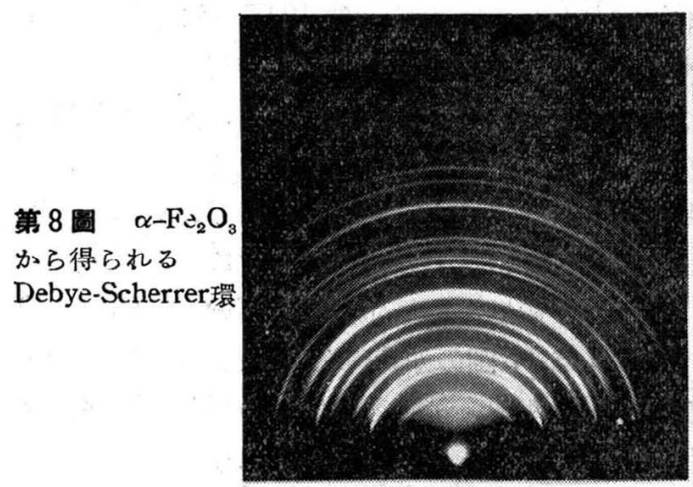

第 9 圖娾延モり ブデン板から得ら れる囩折像, 繊維 軸 [100]が表面に 㨁角になっている

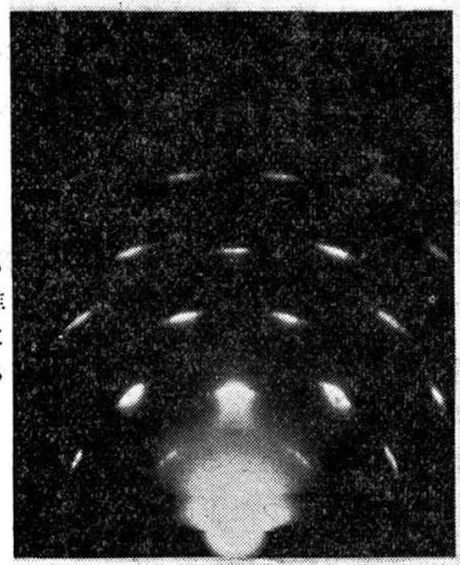

第10圖 $\beta$ 长鍮の 伥磨 (右一左) 面 上の纖維組織表皮 屏は $\alpha$ 㠱鍮に變態 [111]が何丸も表 面一の垂線から嫄 磨方向に約 $6^{\circ}$ 傾 いている。 結晶 (111) 面加ら 得られる司折像。 電子線 11 [ 110 ] し, 緎維軸 [100],

第11圆 $\alpha$ 真鍮單
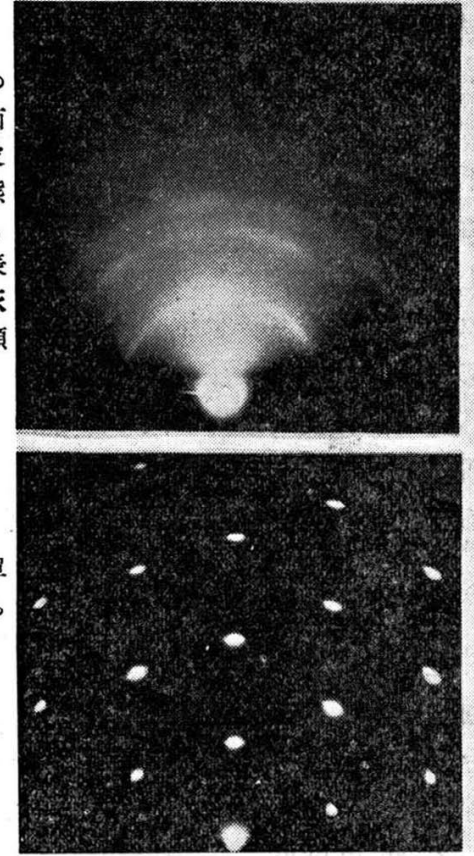

存在しても燃燒し去つている樣な場合ならば比較 的問題はないが，機械仕上面の樣に油脂類を使用 した表面に就ては，適當な溶媒に依つて十分表面

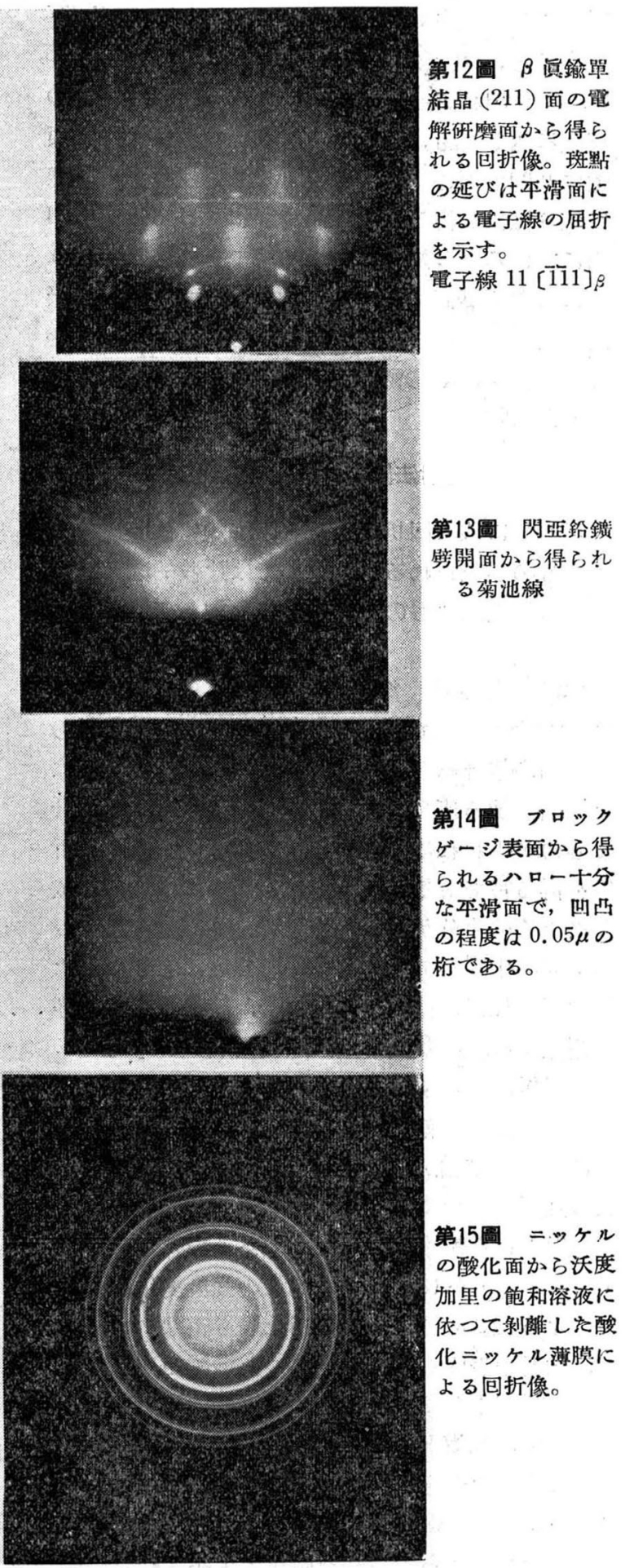

を洗涤せねばならなん。份この際溶媒自體が表面 物質を侵す樣な事のない樣留意すべきである。鍍 金, 電解研势, 腐蝕等の研究に於けるが如く, 金 
屬自體が溶液中にある場合には出來る丈その㦎の 狀態の再現に注意すべきで, 乾燥等は速やかに行 几，或は特殊の方法（例えば純粹な溶媒で洗つて 液を表面にのせた儘裝置中に入れて排氣する等) を用んて, 目的の過程以外の變化 (酸化等) が起 る事を避くべきである。又回折像の解釋に當つて は撮影時に試料が高真空中にあつて, 完全に乾燥 した狀態にある事を考慮に入れるバきで，餘りに 回折像丈をたよりにして結論を急ぐと誤つた絬果 に陷り易々。

何電子间折に依り研究し得る表面に就て一言す る。反射像を生ずる理論から明な通り，餘りに凹 凸の激しい表面例えば粗目の錿で仕上げた樣な表 面の研究には電子回折は不適である。叉回折像が 得られる場合でも適賞に工夫して鮮銳な像が得ら れる樣にすべきである。例えば鐵鋼類では餘りに 細目の0000番のエメリー紙より反つて稍及粗目の 00 番位のエメリー紙で仕上げた表面の方がよく， アルミニウムの樣に殆ど回折像が得られない表面 に粗レ凸起を作つてやつて像を得る如きである。 要するに反射法の真の意味をよく㨔んで實驗を行 えば間違なん。

金屬表面は上記の如〈直接表面に電子線を當て て包折像を調べるのが常道であるが, 試料に依つ ては問題の皮膜を剝ぎ取り，之を透過法に依つて 檢する事も可能である。特に酸化物皮膜に就てこ の事が適用出來る。即ち種及の方法で出來た酸化 表面を適當の試薬で，地金との間を腐蝕して酸化 物皮膜丈を剝離し，透過法で調べるのである。第 15圖に酸化ニッケルに就て一例を示した。鍍金等 の場合にも工夫すれば皮膜剥離法が適用出來る。

\section{5. 結言}

以上極めて大雜把乍ら電子问折法に低る金屬表 面の硎究に就て概說した。電子包折は金虽表面研 究に有力な武器ではあるが，實驗方法が厄介なの で工學方面には未だ十分活用されているとは云い 難い。今後理學者に低つてなされた基礎的研究を 應用して, 複雜多岐な現場の問題の解決が一段と 促進せられん事を事心新つて擱筆する次第であ る。

晌㖶用各分野の詳紐に就ては言及する餘裕がなかつた が，參考文㫫を擧げておくからとれに就て研究される樣 希望する。何本稿の寫真は全部筆者撮影のものである。

\section{參 考 交塥}

1. 電子回折一般（最近のもの以外は應肪方面を訬。述し そものに限つた)

G. I. Finch and H. Wilman, Ergebn. d. exakt. Naturwiss., 16353 (1937)

G. I. Finch, La Diffraction des électrons et la structure des surfaces (1937) 應用方面の叙 述に詳しい見事せ舁窅が多い。

G.P.Thomson and W. Cochrane, Theory end Practice of Electron Diffraction (1939) 電 于问折全般に亘る代表的名藩。

本庄五郎, 電子線回折(物性論数書第 2 卷賽驗技術( 上.)) （昭. 23）最近の技術的發達迄說明してむる。

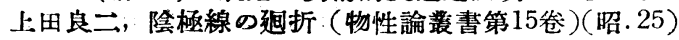
動力學的理論に詳しい。

2. 鑲金

G. I. Finch and C.H. Sun, Trans. Farad. Soc., 32, 852 (1936) 反射法の外鍍金皮膜を㓥離し て透過法で調へてある。

W. Cochrane, Proc. Phys. Soc. 48, 723 (1936) 特に $\mathrm{Ni}$ が反復双晶をなしつつ成長するといら 說を提唱しを點に於て一讀すべき論交。

吉上, 日本數學物理學會誌, 第 17 卷 535 頁(昭. 18) 吉田進, 日本物理學會誌, 第 1 卷 1 頁 (昭. 21)

吉田進, 日本金屬學會誌, 第 8 罕 564 及び 568 頁 (昭.

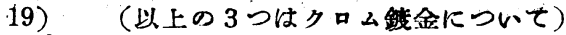

\section{3. 西解研奥}

$$
\text { (以上の } 3 \text { つはクロム鐔金について) }
$$

K. H, Moore, Ann. d. Phys., 33, 133 (1938) 銅 單結晶

W. Kranert, K. H. Leise u. H. Raether, Zeits. f. Phys., 122, 248 (1944) 銅單結晶

H. Raether, Métaux et Corrosion. 22, 2(1947) 電 解及び機械研磨面の構造

H. Raether, Métaux et Corrosion. 24, 145 (1949) 亞鉛㕵楛晶

H. Raether, Métaux et Corrosion, 25, 1 (1950) アルミンウム單結晶

N. Takahashi, Métaux et Corrosion, 25, 37(1950) $\alpha$ 及び $\beta$ 眞鍮單結晶

高橋昇, 理研营報, 第 22 卷 1 頁 (炤. 18) 銅

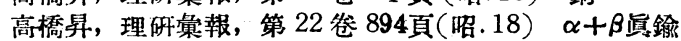

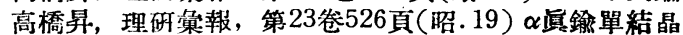

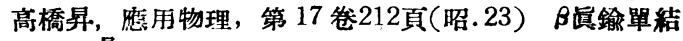
晶

山口成人, 科研報告, 第 25 矮 290頁（炤. 24） 18-8 不銹鋼

4. 機械任上

N, Takahashi and T. Asaeda, Journ. Sci. Res. Inst., 45, 23 (1951) ラップ仕上

N. Takahashi Métaux et Corrosion, 26, (1951) （出版濟なれど未着）各種面心立方格子合金の 表面構造

高橋昇, 理研智報, 第 24 卷 43 頁(昭. 22) $\alpha$ 国鍮單結 晶

高橋昇, 應用物理, 第 17 卷 155頁及び269頁 (昭. 23) フップ仕上

以上の外高良武氏の Beilby 層に關する業績があるか， 交獻名を忘失しそので，御入用の方は九大工學部同氏 宛照會され度い。

5. 腐触, 酸化

H. Yoshioka, J. Phys. Soc. Jap., 4, 270 (1949) 鐵銹

山口成人, 理研畄報, 22,26 (1943) 之以前にも多 くの業績がある。

本生五郎, 日本物理學會誌, 第 4 卷（昭. 24）銅合金 の酸化。 